\title{
Co-infusion of Autologous Adipose Tissue Derived Insulin-secreting Mesenchymal Stem Cells and Bone Marrow Derived Hematopoietic Stem Cells: Viable Therapy for Type III.C. a Diabetes Mellitus
}

\author{
Umang G. Thakkar ${ }^{1}$, Aruna V. Vanikar ${ }^{2}$, Hargovind L. Trivedi ${ }^{1,3}$
}

\begin{abstract}
Transition from acute pancreatitis to insulin-dependent diabetes mellitus (IDDM) is a rare manifestation of primary hyperparathyroidism caused by parathyroid adenoma because of impaired glucose tolerance and suppresses insulin secretion. We report the case of a 26-year-old male with pancreatic diabetes caused by parathyroid adenoma induced chronic pancreatitis. He had serum C-peptide $0.12 \mathrm{ng} / \mathrm{ml}$, glutamic acid decarboxylase antibody $5.0 \mathrm{IU} / \mathrm{ml}$, and glycosylated hemoglobin (HbA1C) $8.9 \%$, and required $72 \mathrm{IU} /$ day of biphasic-isophane insulin injection for uncontrolled hyperglycemia. We treated him with his own adipose tissue derived insulin-secreting mesenchymal stem-cells (IS-ADMSC) along with his bone marrow derived hematopoietic stem cells (BM-HSC). Autologous IS-ADMSC + BM-HSC were infused into subcutaneous tissue, portal and thymic circulation without any conditioning. Over a follow-up of 27 months, the patient is maintaining fasting and postprandial blood sugar levels of 132 and $165 \mathrm{mg} / \mathrm{dl}$, respectively, with HbA1C $6.8 \%$ and requiring $36 \mathrm{IU} /$ day of biphasic-isophane insulin. Co-infusion of IS-ADMSC + BM-HSC offers a safe and viable therapy for type III.C.a Diabetes Mellitus. (Biomed J 2013;36:304-307)
\end{abstract}

\section{Key words: acute pancreatitis and insulin-dependent diabetes mellitus, insulin-secreting mesenchymal stem cells, parathyroid adenoma, stem cell therapy}

$\mathrm{D}$ iabetes occurs in $50-75 \%$ of chronic pancreatitis patients and up to $90 \%$ of calcific chronic pancreatitis patients, but is likely to be underestimated. Literature review has shown that the incidence of diabetes mellitus in patients with primary hyperparathyroidism (PHPT) and, conversely, the incidence of PHPT in diabetic patients are reported approximately threefold higher than the respective expected prevalence. ${ }^{[1]}$ Recent guidelines categorize pancreatic diabetes as type III.C.a and ascribe this to insulinopenia, but there is evidence that glucose intolerance and insulin resistance frequently coexist in chronic pancreatitis. ${ }^{[2]}$ We report the case of a 26-year-old male who underwent stem cell therapy (SCT) for uncontrolled hyperglycemia. He was a case of insulin-dependent diabetes mellitus (IDDM) secondary to chronic calcified pancreatitis that developed after a history of hyperparathyroidism.

\section{CASE REPORT}

A 26-year-old married man, a known case of diabetes mellitus (DM) since 2006, weighing $70 \mathrm{~kg}$ and of height $176 \mathrm{~cm}$, was admitted to G. R. Doshi and K. M. Mehta Institute of Kidney Diseases and Research Centre-Dr. H. L. Trivedi Institute of Transplantation Sciences for SCT of his uncontrolled hyperglycemia. He had past history of recurrent acute pancreatitis (AP) and had been managed conservatively since 2002, which became acute-on-chronic after documenting inhomogeneous pancreas with altered peripancreatic fat on magnetic resonance cholangiopancreaticogram in 2004. In 2006, PHPT was suspected because of the following findings: Serum calcium $12.9 \mathrm{mg} /$ $\mathrm{dl}$, phosphate $2.0 \mathrm{mg} / \mathrm{dl}$, albumin $4.6 \mathrm{~g} / \mathrm{dl}$, and alkaline phosphatase 244 U/l. Subsequently, elevated parathyroid hormone (662 pg/dl, normal range $12-72 \mathrm{pg} / \mathrm{dl}$ ) was observed and a hypoechoic parathyroid lesion of size $2.3 \times 1.4 \mathrm{~cm}$ was found by ultrasonography at the lower pole of left thyroid. A left parathyroid adenoma was confirmed by radionuclide $99 \mathrm{mTC}$ methoxyisobutylisonitrile parathyroid scan [Figure 1]. Because calcific densities were

From the ${ }^{1}$ Department of Regenerative Medicine; ${ }^{2}$ Department of Pathology, Laboratory Medicine, Transfusion Services and Immunohematology; ${ }^{3}$ Department of Nephrology and Transplantation Medicine, G. R. Doshi and K. M. Mehta Institute of Kidney Diseases and Research Centre, India

Received: Jun. 9, 2013; Accepted: Sep. 5, 2013

Correspondence to: Dr. Umang G. Thakkar, Department of Regenerative Medicine, G. R. Doshi and K. M. Mehta Institute of Kidney Diseases and Research Centre (IKDRC). Gujarat - 380 016, India. Tel: 91-79-22687043, Fax: 91-79-22685454; E-mail: umangpaedia@yahoo.co.in

DOI: $10.4103 / 2319-4170.122898$ 
found in the head and uncinate process of the pancreas, the parathyroid adenoma was surgically removed [Figure 1] in 2006, based on the assumption that parathyroid adenoma induced chronic calcific pancreatitis. The postoperative period was uneventful with normal serum calcium and he was free of pancreatitis recurrence; nevertheless, the patient eventually developed DM 4 years after successful parathyroidectomy. There was no evidence of pituitary adenoma also. During admission, he had normal vital parameters with unremarkable systemic examination. He had fasting blood sugar (FBS) and postprandial blood sugar (PPBS) of 205 and $389 \mathrm{mg} / \mathrm{dl}$, respectively. The glycosylated hemoglobin (HbA1C) measured $8.9 \%$, with serum C-peptide measuring 0.12 (normal range: $0.7-1.2$ ) $\mathrm{ng} / \mathrm{ml}$, glutamic acid decarboxylase antibody showing a level of $5 \mathrm{IU} /$ $\mathrm{ml}$ (normal range: $<10 \mathrm{IU} / \mathrm{ml}$ ), and serum acetone level was $10 \mathrm{mg} / \mathrm{dl}$ (reference range up to $10 \mathrm{mg} / \mathrm{dl}$ ). Hematological and biochemical investigations were normal, including renal and liver function tests, serum electrolytes, lipid profile [total cholesterol $178 \mathrm{mg} / \mathrm{dl}$, triglyceride $148 \mathrm{mg} /$ $\mathrm{dl}$, low density lipoprotein (LDL) cholesterol $75 \mathrm{mg} / \mathrm{dl}$, and high density lipoprotein (HDL) cholesterol $42 \mathrm{mg} / \mathrm{dl}$ ], serum calcium $9.0 \mathrm{mg} / \mathrm{dl}$ (normal range: $8.8-10.5 \mathrm{mg} / \mathrm{dl}$ ), serum phosphorus $3.6 \mathrm{mg} / \mathrm{dl}$, intact parathyroid hormone $33 \mathrm{pg} / \mathrm{ml}, 25-(\mathrm{OH})-\mathrm{D} 327.34 \mathrm{pg} / \mathrm{ml}$, and serum albumin $4.6 \mathrm{~g} / \mathrm{dl}$. He was on $72 \mathrm{IU} /$ day of biphasic-isophane insulin injection for uncontrolled hyperglycemia. Fundus examination was normal. He had no other risk factors for progression of chronic pancreatitis, and had unremarkable family and personal history.

He was subjected to SCT after obtaining informed consent from him and approval from the Institutional Review Board. Insulin-secreting adipose tissue derived mesenchymal stem cells (IS-ADMSC) were generated

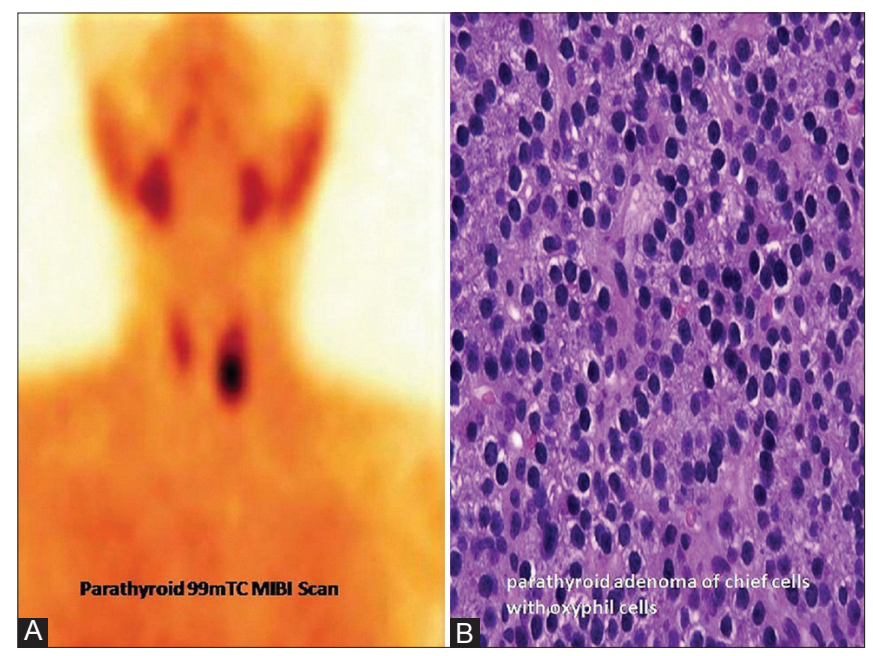

Figure 1: (A) Radionuclide parathyroid scan (99mTC MIBI) showing a left parathyroid adenoma; (B) $\mathrm{H}$ and $\mathrm{E}$ staining of parathyroid adenoma showing chief cells with oxyphil cells. as per our previously described technique with $10 \mathrm{~g}$ of autologous adipose tissue from the anterior abdominal wall on day 1 under local anesthesia (LA). ${ }^{[3]}$ This was subjected to generate in vitro MSC on day 11, which further differentiated into insulin-secreting cells on day 14 that were quantified and tested for sterility, viability, and insulin-secreting markers (pax-6, ipf-1, and isl-1) by immunofluorescence. C-peptide and insulin secretion were tested by chemiluminescence assay (Lumax, Lake Forest, CA, USA). Also, $100 \mathrm{ml}$ bone marrow (BM) was aspirated from posterior superior iliac crest under LA on day 10 , followed by administration of $300 \mu \mathrm{g}$ granulocyte colony stimulating factor subcutaneously on day 8 and 9 for in vitro generation of hematopoietic stem cell (HSC). On day 14, $4 \mathrm{ml}$ IS-ADMSC containing $2 \times 10^{3}$ cells $/ \mu \mathrm{l}$ with $\mathrm{CD}^{+} 0^{+}(39.81 \%)$ and $\mathrm{CD}^{+} 3^{+}(24.07 \%)$, and $95 \mathrm{ml}$ HSC containing $2.6 \times 10^{4}$ cells $/ \mu 1$ with $\mathrm{CD} 34^{+}(0.1 \%)$ were infused into the subcutaneous tissue $(15 \mathrm{ml})$ and superior mesenteric artery through portal route $(76 \mathrm{ml})+$ brachiocephelic artery to thymic $(2 \mathrm{ml})$ circulation via femoral artery catheterization under LA uneventfully. Patient's blood sugar levels were monitored 4 hourly for the first 2 days after stem cell infusion. He was discharged at the end of third day and was advised to take insulin according to the sliding scale of insulin required based on blood sugar levels, and to monitor the FBS and PPBS daily for 5 days and then weekly for the first month, fortnightly for the next 2 months, and monthly thereafter till the end of 1 year. Subsequently, he was advised to check HbA1C every 3 months. Over a follow-up of 27 months [Figure 2], patient is maintaining FBS and PPBS of 132 and $165 \mathrm{mg} / \mathrm{dl}$, respectively, with HbA1C $6.8 \%$, increase in C-peptide from 0.12 to $0.55 \mathrm{ng} /$ $\mathrm{ml}$, and requiring $36 \mathrm{IU} /$ day of biphasic-isophane insulin. There were no untoward side effects recorded. This proved to be a safe, effective, reproducible, and viable therapeutic option.

\section{DISCUSSION}

In patients with insulin-dependent diabetes secondary to chronic pancreatitis, beta cell function is preserved to a greater extent and glucoregulation is better than in type 1 diabetes mellitus (T1DM) patients. Immunological phenomena and associations with certain human leukocyte antigen (HLA) alleles characterizing T1DM are not found in insulin-dependent diabetes secondary to chronic pancreatitis. This may contribute to the slower destruction of the beta cells in chronic pancreatitis than encountered in T1DM. AP is an exceptionally rare consequence of PHPT producing hypercalcemia due to parathyroid adenoma and the reported incidence ranges from $0.23 \%$ to $6.8 \% .{ }^{[4]}$ Eight female patients suffering from PHPT and IDDM have been reported.$^{[5]}$ 


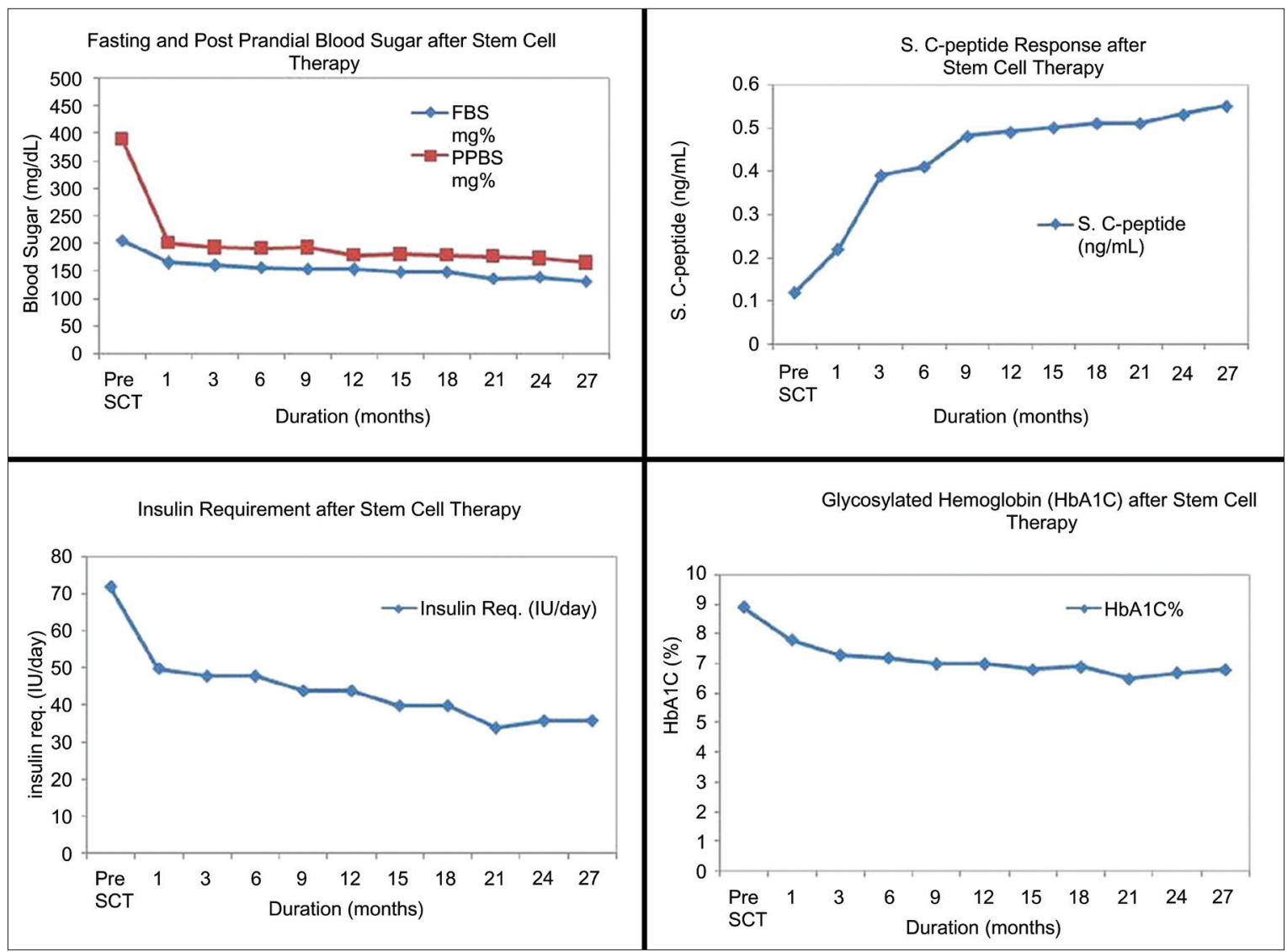

Figure 2: Response obtained in fasting blood sugar, postprandial blood sugar, glycosylated hemoglobin, C-peptide, and insulin requirement after stem cell therapy. Abbreviation used: HbA1C: Glycosylated hemoglobin

MSCs are able to serve as a cellular vehicle for the expression of human insulin gene and have promising therapeutic role in the correction of metabolic derangement of DM and also in controlling and reverting complications in diabetics. ${ }^{[6]}$ We have generated in vitro IS-ADMSC and treated 12 IDDM patients previously, and they have sustained control of IDDM with raised C-peptide levels and controlled Hb1 Ac. ${ }^{[3]}$ The HSCs were used along with IS-ADMSC because HSC infusion with conditioning is believed to create active and passive tolerance by clonal deletion/T-cell suppression. ${ }^{[7]}$ Hence, we decided to explore this protocol which has already given sustained benefits without any adverse effects and decided to infuse the cells in thymic circulation to achieve central tolerance and in portal circulation since liver is the most tolerogenic organ. ${ }^{[8,9]}$ Subcutaneous tissue, being an immunologically privileged site, we decided to inject part of the cells in abdominal subcutaneous tissue, so that it will serve as a "back-up reservoir" for insulin supply. ${ }^{[10]}$

To the best of our knowledge, this is the first case report of successfully treating type III.C.a diabetic patient with SCT. IS-ADMSC and BM-HSC co-infusion could provide better diabetic control, and therefore, could be a simple, safe and effective therapy for future diabetic therapy.

\section{Conclusion}

Co-infusion of IS-ADMSC + BM-HSC offers a safe and viable therapy for type III.C.a diabetes mellitus.

\section{REFERENCES}

1. Gulcelik NE, Bozkurt F, Tezel GG, Kaynaroglu V, Erbas T. Normal parathyroid hormone levels in a diabetic patient with parathyroid adenoma. Endocrine 2009;35:147-50.

2. DiMagno MJ, Dimagno EP. Chronic pancreatitis. Curr Opin Gastroenterol 2006;22:487-97.

3. Vanikar AV, Dave SD, Thakkar UG, Trivedi HL. Co-transplantation of adipose tissue derived insulin-secreting mesenchymal stem cells and hematopoietic stem cells: A novel therapy for insulin-dependent diabetes mellitus. Stem Cells Int 2010;2010:582382.

4. Akce M, Wasco M, Kimball B, Saberi S. Acute pancreatitis as the first manifestation of parathyroid adenoma. J Endocrinol Metab 2012;2:187-9.

5. Walsh CH, Soler NG, Malins JM. Diabetes mellitus and primary hyperparathyroidism. Postgrad Med J 1975;51:446-9. 
6. Zhang N, Li J, Jiang J, Wang JA. Bone marrow mesenchymal stem cells induce angiogenesis and attenuate the remodeling of diabetic cardiomyopathy. Exp Clin Endocrinol Diabetes 2008;116:104-11.

7. Trivedi HL, Vanikar AV, Thakker U, Firoze A, Dave SD, Patel CN, et al. Human adipose tissue-derived mesenchymal stem cells combined with hematopoietic stem cell transplantation synthesize insulin. Transplant Proc 2008;40:1135-9.
8. Sprent J, Kishimoto H. The thymus and central tolerance. Philos Trans R Soc Lond B Biol Sci 2001;356:609-16.

9. Starzl TE. The "Privileged" Liver and Hepatic Tolerogenicity. Liver Transpl 2001;7:918-20.

10. Prokhorova TA, Harkness LM, Frandsen U, Ditzel N, Schroder HD, Burns JS, et al. Teratoma formation by human embryonic stem cells is site dependent and enhanced by the presence of Matrigel. Stem Cells Dev 2009;18:47-54. 